\title{
Assessment of knowledge of midwives about the scope of professional responsibility under the amended provisions of law
}

\begin{abstract}
Introduction. To work safely, knowledge of law is crucial for midwives who should be familiar with the midwife's rights and duties as well as their professional responsibility.

Aim. Assessment of knowledge of midwives about their professional responsibility.

Material and methods. A total of 103 MA Midwifery students of the Medical University of Warsaw, including 55 working and 48 not working as midwives. A diagnostic poll, original anonymous questionnaire, 25 close-ended questions, 8 openended questions. Statistical analysis: STATISTICA 10.0, Mann-Whitney U test, $\mathrm{p}<0.05$.

Results. Seventy-one percent of the study participants had knowledge of the binding provisions of law and $83 \%$ considered this kind of knowledge as necessary in their professional activity. Twenty-four percent of the total did not know any legal regulations. Thirty percent was not familiar with the Nurses and Midwives Act. Only 52\% of the study participants were knowledgeable about the legal protection of midwives and indicated the protection established for public officers. Forty-six percent of the total said that the Act on Professional Self-Government of Nurses and Midwives of July 1st, 2011 regulates the issue of self-governance. As many as 30 study participants knew that membership in the self-governing body of midwives is obligatory.

Conclusions. Knowledge of nurses about professional responsibility under amended provisions of law is insufficient and does not improve with experience as a midwife. Due to the fact that new acts on professional responsibility of midwives were implemented in Poland beginning in January 1st, 2012, it is advisable to extend qualifications and knowledge of midwives in order to improve their knowledge of professional issues. Midwives should constantly update their knowledge of legal regulations on their profession.
\end{abstract}

Keywords: midwifery, professional responsibility, provisions of law.

DOI: $10.2478 /$ pjph-2014-0004

\section{INTRODUCTION}

At present, the profession of a midwife puts high demands of society towards midwives. Proper qualifications, competence, professionalism, and experience constitute crucial criteria to make a choice. Changes undergoing in modern midwifery allow for greater independence of midwives in their professional activity. A great modification of the role of midwives during labour and in maternity care results from medicalization and changed social awareness. A midwife used to care for a woman at any age and in all respects and a pregnant woman hardly ever had a contact with a gynaecologist. Following the provisions of the Nurses and Midwives Act of July 15th, 2011, "the professions of nurse and midwife are independent professions"; therefore, a midwife recognizes and accepts her professional and personal responsibility for the performance of professional activities [1]. Knowledge and understanding of ethical and deontological norms, bind- ing legal regulations and procedures associated with the latter are crucial for safe and efficient work in the profession of midwife who is obliged to know the rights and duties associated with her profession as well as the responsibility related to it [2]. Responsibility in a broad sense involves also its specific kind, i.e. professional responsibility, which is associated with being a member of a particular professional group and with being allowed to act independently within this group. Professional responsibility of health professionals towards ethics may be considered contrary to or violating the legal regulations now in force by persons of medical professions, midwives included [3].

\section{AIM}

An attempt to assess the knowledge of professional responsibility among midwives starting an MA Midwifery course at Medical University of Warsaw. A detailed aim

\footnotetext{
${ }^{1}$ Division of Teaching and Outcomes of Education, Faculty of Health Science, Medical University of Warsaw, Poland

${ }^{2}$ Division of Public Health, Faculty of Health Science, Medical University of Warsaw, Poland

${ }^{3}$ Division of Community Nursing, Faculty of Health Science, Medical University of Warsaw, Poland
} 
of the study was an attempt to assess the knowledge of midwives about the scope of professional responsibility under the amended legal regulations in relation to being (or not) a practising midwife.

\section{MATERIAL AND METHODS}

The study was conducted in the academic year 2012/2013 among 103 regular and extramural MA Midwifery students at Medical University of Warsaw. Group 1 comprised 55 students who were working as midwives, whereas Group 2 included the remaining 48 who were not working in the chosen profession at the time of the present study. A diagnostic poll method with a survey technique was used in the study. The study was carried out between February and March 2013 with the use of a questionnaire developed by the authors. Participation in the study was voluntary and the questionnaire was anonymous. The questionnaire comprised 25 close-ended single choice questions concerning various aspects relating to professional responsibility in the selected professional group and 8 open-ended questions designed to assess the level of knowledge of midwives about the amended provisions of law relating to professional responsibility.

\section{Statistical analysis of the study results}

The data were collected in the Microsoft Excel program. Two groups of midwives were compared: Group 1 comprised MA students who were working as midwives, whereas Group 2 involved those MA students who were not working as midwives at the time of the present study. Statsoft STATISTICA 10.0 (licensed to Warsaw Medical University) and non-parametric statistical Mann-Whitney U test were used for statistical analysis. The significance level was established at $\mathrm{p}<0.05$.

\section{RESULTS}

Among the study group of MA Midwifery students, employment as midwives did not influence the level of knowledge of professional responsibility under the amended provisions of law. The level of knowledge of the amended provisions of law regulating the issues of professional responsibility among Group 1 (students employed as midwives) and Group 2 (students not employed as midwives) was insufficient. See Table 1 for details on the level of knowledge of professional responsibility among the study group.

TABLE 1. Knowledge of professional responsibility among the study group of midwives.

\begin{tabular}{|c|c|c|c|c|c|}
\hline & Question & $\begin{array}{l}\text { The } \\
\text { entire } \\
\text { group }\end{array}$ & $\begin{array}{c}\text { Group } \\
1\end{array}$ & $\begin{array}{l}\text { Group } \\
2\end{array}$ & $\mathrm{p}$ \\
\hline \multirow{3}{*}{$\begin{array}{l}\text { Have you become acquainted with legal } \\
\text { regulations on the profession of midwife? }\end{array}$} & - yes & 73 & 40 & 33 & \multirow{3}{*}{0.977} \\
\hline & - no & 25 & 12 & 13 & \\
\hline & - do not know & 5 & 3 & 2 & \\
\hline \multirow{3}{*}{$\begin{array}{l}\text { Do you think that knowledge of legal regu- } \\
\text { lations is necessary in professional activity } \\
\text { of a midwife? }\end{array}$} & - yes & 86 & 44 & 42 & \multirow{3}{*}{0.144} \\
\hline & - no & 3 & 3 & 0 & \\
\hline & - do not know & 14 & 8 & 6 & \\
\hline \multirow{4}{*}{$\begin{array}{l}\text { Nurses and Midwives Act now } \\
\text { in force was passed on: }\end{array}$} & - the 1st of January, 2012. & 6 & 5 & 1 & \multirow{4}{*}{0.030} \\
\hline & - the 15 th of July, 2011. & 63 & 25 & 38 & \\
\hline & - the 1st of July, 2011. & 8 & 5 & 3 & \\
\hline & - the 15 th of July, 1996. & 26 & 20 & 6 & \\
\hline \multirow{5}{*}{$\begin{array}{l}\text { Who can perform } \\
\text { the profession of a midwife? }\end{array}$} & - a person who graduated from a medical school & 0 & 0 & 0 & \multirow{5}{*}{0.001} \\
\hline & - a person who graduated from a medical school & 19 & 18 & 1 & \\
\hline & with a major in Midwifery & & & & \\
\hline & - a person who has the right to practise the profession of a midwife & 7 & 5 & 2 & \\
\hline & - a person who has a valid right to practise the profession of a midwife & 77 & 32 & 45 & \\
\hline \multirow{4}{*}{$\begin{array}{l}\text { The Minister of Health defines the type and } \\
\text { range of health services that can be provided } \\
\text { by a midwife independently without } \\
\text { a physician's instruction in the form of: }\end{array}$} & - a regulation & 61 & 35 & 26 & \multirow{4}{*}{0.079} \\
\hline & - a resolution & 1 & 1 & 0 & \\
\hline & - an act & 40 & 19 & 21 & \\
\hline & - a directive & 1 & 0 & 1 & \\
\hline \multirow{4}{*}{$\begin{array}{l}\text { Which of the following cannot be performed } \\
\text { by a midwife independently without } \\
\text { a physician's instruction? }\end{array}$} & - manual removal of the placenta in the case of haemorrhage & 51 & 28 & 23 & \multirow{4}{*}{0.562} \\
\hline & - urinary bladder catheterization and removal of a catheter & 1 & 0 & 1 & \\
\hline & $\begin{array}{l}\text { - designing a diet in particular periods of a woman's life, } \\
\text { in physiological pregnancy and in high-risk pregnancy }\end{array}$ & 2 & 1 & 1 & \\
\hline & - placement of a gastric tube and removal of the gastric contents & 49 & 26 & 23 & \\
\hline \multirow{4}{*}{$\begin{array}{l}\text { Which of the following diagnostic actions } \\
\text { performed by a midwife requires } \\
\text { a physician's instruction? }\end{array}$} & - suction of the respiratory tract & 22 & 12 & 10 & \multirow{4}{*}{0.363} \\
\hline & - pulse oximetry & 1 & 0 & 1 & \\
\hline & - urinary bladder irrigation & 70 & 36 & 34 & \\
\hline & - removal of sutures from the perineum & 10 & 7 & 3 & \\
\hline \multirow{4}{*}{$\begin{array}{l}\text { State, which rehabilitation service may be } \\
\text { performed by a midwife independently } \\
\text { without a physician's instruction. }\end{array}$} & - bedside rehabilitation performed to prevent complications & 79 & 44 & 35 & \multirow{4}{*}{0.314} \\
\hline & - urinary bladder training & 11 & 6 & 5 & \\
\hline & - applying for social care for a patient & 2 & 2 & 0 & \\
\hline & - rehabilitation of persons with psychological disorders & 11 & 3 & 8 & \\
\hline \multirow{3}{*}{$\begin{array}{l}\text { A midwife who provides health services } \\
\text { is protected the same way as: }\end{array}$} & - public officer & 54 & 30 & 24 & \multirow{3}{*}{0.649} \\
\hline & - medical officer & 49 & 25 & 24 & \\
\hline & - social officer & 0 & 0 & 0 & \\
\hline \multirow{3}{*}{$\begin{array}{l}\text { Can a midwife refuse to execute } \\
\text { a physician's instruction? }\end{array}$} & - yes & 99 & 52 & 47 & \multirow{3}{*}{0.385} \\
\hline & - no & 0 & 0 & 0 & \\
\hline & - do not know & 4 & 3 & 1 & \\
\hline
\end{tabular}




\section{DISCUSSION}

The available Polish and foreign literature presents topics related to professional responsibility of members of medical professions in many dimensions [2,4-10]. Most of these publications relate to the Code of Professional Conduct of Nurses and Midwives and Act on the Profession of Nurse and Midwife $[6-8,11,12]$. No publications were found on the knowledge of the Act on Professional Self-Government of Nurses and Midwives among midwives.

The issue of professional responsibility of nurses and midwives is discussed in most publications devoted to the knowledge of the provisions of law regulating practising the professions mentioned above [2-12].
A study by Rozwadowska et al. [6] analysed the knowledge of the Act on the Profession of Nurse and Midwife. The study among 273 Nursing and Midwifery students as well as practising nurses and midwives analysed the answers provided by the study participants with reference to the aforementioned Act. The study results demonstrated that a majority of the study participants rightly considered the following statement false: "A nurse/midwife who is a citizen of a Member State of the EU cannot be granted the right to practice the profession within the territory of the Republic of Poland". A similar answer was also given to the following statement: "The duty of confidentiality of a nurse/midwife terminates when a patient dies". Most of the study group presented wide knowledge of the provisions of law applicable to nurses. As many as $85 \%$ of the respondents incorrectly

TABLE 1. continued

\begin{tabular}{|c|c|c|c|c|c|}
\hline \multirow{4}{*}{$\begin{array}{l}\text { Can a midwife inform patients } \\
\text { about their health? }\end{array}$} & - yes, in all circumstances & 3 & 1 & 2 & \multirow{4}{*}{0.250} \\
\hline & - yes, but only to the extent necessary for nursing care & 88 & 46 & 42 & \\
\hline & - no, only a physician can give such information to the patient & 12 & 8 & 4 & \\
\hline & - do not know & 0 & 0 & 0 & \\
\hline \multirow{3}{*}{$\begin{array}{l}\text { Can a midwife refuse to change } \\
\text { the form of practising her profession? }\end{array}$} & - yes & 52 & 25 & 27 & \multirow{3}{*}{0.573} \\
\hline & - no, because this will result in termination of employment relationship & 6 & 4 & 2 & \\
\hline & - do not know & 45 & 26 & 19 & \\
\hline \multirow{3}{*}{$\begin{array}{l}\text { Can a midwife, under Polish law, provide } \\
\text { additional nursing care in a health care } \\
\text { entity such as a hospital? }\end{array}$} & - yes & 93 & 50 & 43 & \multirow{3}{*}{0.985} \\
\hline & - no & 3 & 2 & 1 & \\
\hline & - do not know & 7 & 3 & 4 & \\
\hline \multirow{4}{*}{$\begin{array}{l}\text { How long does it take to train a midwife } \\
\text { with a } 6 \text {-year career break? }\end{array}$} & - not shorter than 6 months & 44 & 26 & 18 & \multirow{4}{*}{0.178} \\
\hline & - not longer than 6 months & 15 & 8 & 7 & \\
\hline & - not shorter than 3 months & 40 & 21 & 19 & \\
\hline & - not longer than 3 months & 4 & 0 & 4 & \\
\hline Does the training of a midwife & - yes & 97 & 55 & 42 & \\
\hline with a career break require & - no & 1 & 0 & 1 & 0.007 \\
\hline supervision of another midwife? & - do not know & 5 & 0 & 5 & \\
\hline \multirow{4}{*}{$\begin{array}{l}\text { Who grants the right to practice } \\
\text { the profession? }\end{array}$} & - Regional Council of Nurses and Midwives & 6 & 5 & 1 & \multirow{4}{*}{0.018} \\
\hline & - Regional Chamber of Nurses and Midwives & 85 & 46 & 39 & \\
\hline & - Supreme Council of Nurses and Midwives & 3 & 2 & 1 & \\
\hline & - Supreme Chamber of Nurses and Midwives & 9 & 2 & 7 & \\
\hline \multirow{3}{*}{$\begin{array}{l}\text { Which legislative act regulates the activity } \\
\text { of the professional self-government? }\end{array}$} & - Nurses and Midwives Act & 29 & 20 & 9 & \multirow{3}{*}{0.295} \\
\hline & - Regulation of the Minister of Health & 26 & 10 & 16 & \\
\hline & - Act on Professional Self-Government & 48 & 25 & 23 & \\
\hline \multirow{4}{*}{$\begin{array}{l}\text { The Act on Professional Self-Government } \\
\text { is valid beginning with: }\end{array}$} & - the 1st of July, 2011. & 53 & 25 & 28 & \multirow{4}{*}{0.124} \\
\hline & - the 7th of July, 1991. & 37 & 23 & 14 & \\
\hline & - the 15 th of July, 2012. & 7 & 4 & 3 & \\
\hline & - the 1 st of October, 2012. & 6 & 3 & 3 & \\
\hline \multirow{3}{*}{$\begin{array}{l}\text { Is the membership in the self-governing } \\
\text { body obligatory? }\end{array}$} & - yes & 30 & 18 & 12 & \multirow{3}{*}{0.007} \\
\hline & - no & 44 & 30 & 14 & \\
\hline & -do not know & 9 & 7 & 22 & \\
\hline \multirow{3}{*}{$\begin{array}{l}\text { Does professional responsibility } \\
\text { apply to midwives? }\end{array}$} & -yes & 101 & 53 & 48 & \multirow{3}{*}{0.188} \\
\hline & - no & 0 & 0 & 0 & \\
\hline & - do not know & 2 & 2 & 0 & \\
\hline \multirow{4}{*}{$\begin{array}{l}\text { Which document is the source of profes- } \\
\text { sional responsibility of midwives? }\end{array}$} & - Code of Professional Conduct of Nurses & 54 & 34 & 20 & \multirow{4}{*}{0.044} \\
\hline & $\begin{array}{l}\text { and Midwives of the Republic of Poland } \\
\text { - Penal Code }\end{array}$ & 39 & 18 & 21 & \\
\hline & - Civil Code & 10 & 3 & 7 & \\
\hline & - Administrative Code & 0 & 0 & 0 & \\
\hline \multirow{3}{*}{$\begin{array}{l}\text { Can the right to practice the profession } \\
\text { expire or be limited? }\end{array}$} & - yes & 99 & 55 & 44 & \multirow{3}{*}{0.030} \\
\hline & - no & 2 & 0 & 2 & \\
\hline & - do not know & 2 & 0 & 2 & \\
\hline & - yes & 102 & 54 & 48 & \\
\hline $\begin{array}{l}\text { Is a midwite obliged to update her knowl- } \\
\text { edge continuously? }\end{array}$ & - no & 0 & 0 & 0 & 0.360 \\
\hline & - do not know & 1 & 1 & 0 & \\
\hline & - after 5 years & 26 & 17 & 9 & \\
\hline $\begin{array}{l}\text { When can a midwife apply for being } \\
\text { admitted to another specialization course }\end{array}$ & - after 3 years & 32 & 13 & 19 & 0.698 \\
\hline co-funded from public sources? & - after 1 year & 16 & 4 & 12 & 0.098 \\
\hline & - there are no such conditions & 29 & 21 & 8 & \\
\hline
\end{tabular}


answered the following question: "Taking on employment as a nurse/midwife 5 years after completion of post-graduate internship or after a career break that lasted longer than 5 years is possible". Thirty-three percent of midwives gave the correct answer to a question concerning the appeal period in the case of suspension of the right to practice the profession for the duration of inability or in the case of restriction in performing certain professional activities for the duration of inability. The respondents proved to be familiar with the issue relating to the obligation of providing first aid to patients in any life-threatening situation. It is worth emphasising that $100 \%$ of the midwives answered correctly the question relating to a refusal to carry out a physician's instruction, providing reasons for the refusal in writing immediately. The study results demonstrated that a vast majority of the study participants were well familiar with the legal regulations. Our study also involved a question relating to the Act on the Profession of Nurse and Midwife. A majority of the study population $(51 \%) \mathrm{knew}$ that this Act was passed on the 1 st of July, 2011, and $57 \%$ of the total said that knowledge of the Act on the Profession of Nurse and Midwife is necessary to practice the profession of midwife.

Grochonas et al. [9] studied the influence of the level of education of nurses on their knowledge of selected legislative acts relating to nursing. The study enrolled 366 practising nurses with the mean length of service of 14 years. The results showed that the knowledge of the legislative acts among nurses with a secondary school degree was at the same level compared to nurses with a higher education degree. Our study results also showed that being a practising midwife does not influence the level of knowledge and answers provided to questions concerning provisions of law regulating the profession of midwife among the Midwifery students participating in the study.

The study by Gawel et al. [5] aimed to assess the awareness of professional responsibility among nurses. It demonstrated the knowledge of legal regulations in force and use of the binding procedures that provide both the patient and medical personnel with safety guarantee. Over $2 / 3$ of the study population knew the scope of professional responsibility. As many as $79 \%$ of the study participants said they were familiar with the Act on the Profession of Nurse and Midwife; $60 \%$ of the total admitted that they were familiar with the Code of Professional Conduct; $40 \%$ of the total reported the knowledge of the Act on Professional SelfGovernment of Nurses and Midwives, whereas $22 \%$ of the total reported the knowledge of the Regulation of the Minister of Health on the range and type of prophylactic, diagnostic, treatment, and rehabilitation services performed by a nurse unassisted and without a physician's instruction. In our study, Midwifery students were also asked about the knowledge of the provisions of law regulating the profession of midwife. Although 73 persons answered that they had knowledge of legal regulations in force, every fifth practising midwife did not have such knowledge.

The obligation to provide first aid in emergency and lifethreatening situations is another issue covered in both the literature $[5,6,8]$ and our study. This is an obligation of any person, particularly of qualified health professionals. Mroczek et al. [8] and Rozwadowska et al. [6] obtained similar results demonstrating that the majority of the study participants considered the statement mentioned above as obvious. In the study by Mroczek et al., 99\% of the students of Pomeranian Medical University in Szczecin responded correctly to a question about providing first aid. In the study by Rozwadowska et al., the correct answer was given by as many as $100 \%$ of the Midwifery students, $96 \%$ of the midwives, $89 \%$ of the Nursing students, and $84 \%$ of the nurses. Almost half of our study participants responded incorrectly by saying that a midwife needs a physician's instruction to remove manually the placenta in the case of haemorrhage, i.e. in a life-threatening situation.

An article by Zaniewicz and Marczewski [13] constitutes another example of common and frequent incompatibility with binding procedures. The study results demonstrated that for a vast majority of the study population the closest environment was the basic source of information on professional duties and for $54 \%$ of the total it was a ward nurse. Ninety-one percent of the respondents gave the correct answer to a question concerning the competence to provide patients and their families with information about their health and prognosis. Our study results showed that a vast majority of students asked whether a midwife could inform patients about their health gave the correct answer, i.e. they knew that a midwife could provide patients with such information, but only to the extent necessary for nursing care. Twelve percent of the study population believed that only a doctor can inform patients about their condition.

Mroczek et al. [8] came to a very interesting conclusion on the level of knowledge of nurses and midwives about the Code of Professional Conduct. Midwives are obliged by the Code of Professional Conduct to share their knowledge and professional skills with other midwives. Seventy-nine percent of the study participants were aware of this fact, while the remaining study participants considered such a solution as an option only in certain circumstances. Ten percent of the study group believed that this is not a moral obligation of nurses. In our study, the students were asked if a midwife was obliged to update her knowledge continuously. Only one person answered "I don't know", while the remaining 102 students knew that midwives have such an obligation.

In our study as well as in the study by Gaweł et al., [5] the study groups were asked about the kind of responsibility of a nurse in the case of failure to provide first aid in a life or health-threatening situation. Sixty-four percent of the respondents in the study by Gawel et al. knew that this is a penal responsibility [5]. In our study, midwives were asked whether they are subject to criminal liability and a vast majority of them (98\%) knew the correct answer, i.e. that they are subject to it. On the other hand, only $38 \%$ of the study population (including as little as $44 \%$ of students not working in their profession) responded correctly to the question about the source of midwife's professional responsibility and knew that it is the Penal Code. Over half of the respondents $(52 \%)$ indicated the Code of Professional Conduct of Nurses and Midwives of the Republic of Poland as the source of midwife's professional responsibility.

Jara [4] also analysed the knowledge of the study participants about the procedures in the case of violation of the principles of professional responsibility. As many as $60 \%$ of 
the study group were not able to list the penalties imposed on nurses who had gone beyond their competences, while $27 \%$ of the total managed to name only a reprimand and financial penalty and, some of them, deprivation of the right to practice the profession. In our study, deprivation of the right to practice the profession was indicated by the most numerous group of respondents and a reprimand and financial penalty were mentioned by a slightly less numerous group, even though as much as $36 \%$ of the total did not know any penalties, including $35 \%$ of those working and $27.5 \%$ of those not working as a midwife.

In our study, only 30 participants (including 18 midwives working in their profession) knew that membership in the self-governing body is obligatory. Forty-three percent of the total responded incorrectly, i.e. that it is not obligatory. As many as $46 \%$ of the midwives not working in their profession said that they did not know, proving that the knowledge of the provisions of law regulating the profession of midwife was insufficient and that the level of knowledge in this field was low.

An analysis of our study results and the available literature $[4-6,8,10,11]$ showed that the level of knowledge of midwives about the amended provisions of law regulating their professional responsibility is insufficient. The knowledge of the rights and duties of the profession is of great importance at work since it ensures safety to patients. A study by Fedak et al. [12] demonstrated that a vast majority of nurses, in fear of going beyond their competences, withdraw from their professional (mainly independent) activities. Our study respondents presented an insufficient level of knowledge, therefore it is advisable to conduct a greater number of workshops and courses on legal regulations that would present and discuss the scope of rights and duties of midwives.

\section{CONCLUSIONS}

1. Knowledge of midwives of professional responsibility under the amended provisions of law is insufficient.

2. The level of knowledge and awareness of professional responsibility among the midwives participating in the study did not improve with taking on employment as midwife.

3. Among the study participants, midwives working in their profession represented the same level of knowledge of professional responsibility as those students not working as midwives.

4. Due to the fact that new acts on professional responsibility of midwives were implemented in Poland beginning in January 1st, 2012, it is advisable to extend qualifications and knowledge of midwives in order to improve their knowledge of the professional issues.

5. Midwives should constantly update their knowledge of legal regulations on their profession.

\section{REFERENCES}

1. Rogala-Pawelczyk G. Odpowiedzialność zawodowa pielęgniarek i położnych. Warszawa: NIPi; 2007.

2. Olechrowicz A, Łapuć M. Odpowiedzialność zawodowa pielęgniarek. Probl Pielęg. 2006;1-2:62-8.

3. Nestorowicz M. Odpowiedzialność cywilna pielęgniarki i położnej, personelu medycznego. In: M. Nestorowicz (ed). Prawo medyczne. Torun: Towarzystwo Naukowe Organizacji i Kierowania; 2005.

4. Jara K. Odpowiedzialność zawodowa pielęgniarki. In: M. Kosińska, L. Niebrój (ed). Poszerzenie Unii Europejskiej: polskie pielęgniarstwo w czasie zmian. Katowice: Wyd. ŚAM; 2005. p.47-51.

5. Gaweł G, Pater B, Potok H, Ogonowska D. Świadomość odpowiedzialności zawodowej wśród pielęgniarek. Probl Pielęg. 2010;18(2):105-10.

6. Rozwadowska E, Krajewska-Kułak E, Kropiwnicka E, et al. Ocena znajomości ustawy o zawodzie pielęgniarki i położnej przez studentów pielęgniarstwa i położnictwa oraz pielęgniarki i położne. Probl Pielęg. 2010;18(4);443-54.

7. Kostrzanowska Z, Małek K. Respektowanie zasad etycznych w pracy zawodowej pielęgniarek. Probl Pielęg. 2008;16(3):259-68.

8. Mroczek B, Kędzia A, Trzaszczka M, et al. Stan wiedzy na temat Kodeksu Etyki Zawodowej wśród pielęgniarek i położnych. Probl Pielęg. 2008;16(4):369-73.

9. Grochonas E, Głowacka T, Szkup-Jabłońska M, et al. Wpływ poziomu wykształcenia pielęgniarek na znajomość wybranych aktów prawnych wykorzystywanych w pielęgniarstwie. Probl Pielęg. 2011;(4):463-7.

10. Kieczka K. Opieka profesjonalna i zakres kompetencji pielęgniarek w Polsce w świetle prawa w ostatnim stuleciu. Pielęg XXI wieku. 2010;1-2(30-31);81-6.

11. Salomon J. Wartości i cnoty etyczne pielęgniarki i ich znaczenie w pracy zawodowej. Onkol Pol. 2005;8(3):177-80.

12. Fedak M, Wieczorek A, Papiernik M, Krupienicz A. Realizacja funkcji zawodowych. Mag Pielęg Poł. 2008;(8):5-8.

13. Zaniewicz A, Marczewski K. Czynności delegowane pielęgniarkom w lecznictwie zamkniętym. Zdr Publ. 2002;112(3):326-9.

\section{Corresponding author}

Dr hab. n. o zdr. Joanna Gotlib

61 Żwirki i Wigury Str., 02-091 Warszawa, Poland

tel. +48 22 57-20-490, fax: +48 22 57-20-491

E-mail: joanna.gotlib@wum.edu.pl 